\title{
Belphégor
}

\section{Sara Wasson and Emily Alder, Gothic Science Fiction}

1980-2010

\section{Sophie Beaulé}

\section{(2) OpenEdition}

1 Journals

\section{Electronic version}

URL: http://journals.openedition.org/belphegor/483

DOI: 10.4000/belphegor.483

ISSN: 1499-7185

\section{Publisher}

LPCM

\section{Electronic reference}

Sophie Beaulé, «Sara Wasson and Emily Alder, Gothic Science Fiction 1980-2010 », Belphégor [Online], 12-1 | 2014, Online since 12 June 2014, connection on 10 December 2020. URL : http:// journals.openedition.org/belphegor/483; DOI : https://doi.org/10.4000/belphegor.483

This text was automatically generated on 10 December 2020.

\section{(c) (i) (9)}

Belphégor est mis à disposition selon les termes de la Licence Creative Commons Attribution - Pas d'Utilisation Commerciale - Pas de Modification 4.0 International. 


\title{
Sara Wasson and Emily Alder, Gothic Science Fiction 1980-2010
}

\author{
Sophie Beaulé
}

\section{REFERENCES}

Sara Wasson and Emily Alder, Gothic Science Fiction 1980-2010. Liverpool Science Fiction Texts and Studies 41. Liverpool University Press, 2011. ISBN 978-1-84631-707-1. 
1 With their collection of essays Gothic Science Fiction 1980-2010, Sara Wasson and Emily Alder illustrate the richness of gothic tropes in contemporary forms, from novels and movies to card games. More than cliché, melodrama, or gore, the "gothick" (to borrow Adam Roberts's term, xi) allows for the hybridity in contemporary production, especially in science fiction, that the collected articles examine.

2 The book is divided into three parts, "Redefining Genres", "Biopower and

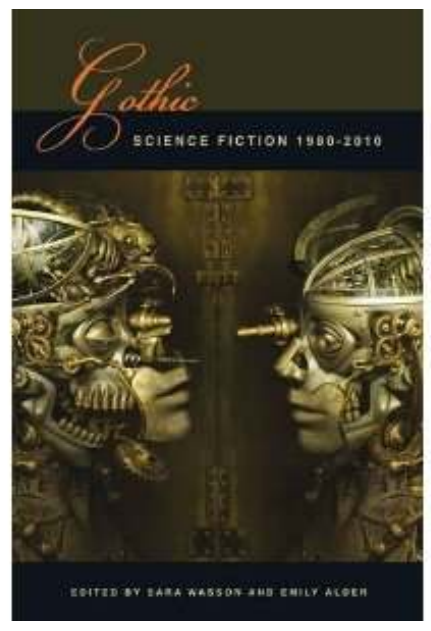
Capital", and "Gender and Genre", which are preceded by an intelligent introduction by the editors. If the quality of the hypotheses developed in the essays or of the writing styles varies, overall the book is an excellent indication of the breadth of the theoretical frames and of the objects of study.

Sara Wasson and Emily Alder underline the fruitful interactions between the gothic mode and science fiction, especially in their vivid illustration of sections of social discourse. Often referring to the contributors' chapters, the editors draw on four orientations in recent gothic science fiction. First, gothic science fiction novels contain taboo pleasures and anxieties related to economic globalization and the rise of national identities. They are also characterized by the trauma and terrors of new technologies, along with the ethical and political questions related to genetic engineering, for instance, or the posthuman. Far from optimistic transhumanist discourse, recent gothic SF presents the cyborg on the side of the abject and the inhuman. Lastly, gothic SF expresses anxieties resulting from the erasing of the human subject in legal discourse, making for a destabilized identity and the apocalyptic potential of technologies. Some of the authors propose that this fear of the transhuman may stem from reactionary ideologies.

Roger Luckhurst's “In the Zone: Topologies of Genre Weirdness" opens the first part of the collection. Gothic SF works, from Thomas Pynchon to China Miéville, can be viewed as examples of the Zone that witness the contemporary hybrid assemblages and comment on their own generic hybridity (23). In this way, Luckhurst and other contributors to this collection signal the shift in science fiction studies away from the interest toward generic purity in favor of hybridity. The Zone is a transitional and social space such as liminal space between warring states or colonial encounter as contact zone. Literature of the Zone would be, then, the hybrid works that emerge between cultures or literatures as coherent and monolithic. Gothic science fiction's "weird spatial zones of genre pile-up" (33) both reflect the generic hybridization and the contemporary "risk society" (33).

Between gothic and science fiction, the figure of the zombie can be related to shifts in political and economical context, along with being revealing at the psychoanalytical level, declares Fred Botting in his "Zombie Death Drive: Between Gothic and Science Fiction". The author takes a particular interest in Victor Halperin's White Zombie (1932), and George Romero's Night of the Living Dead (1968) and Dawn of the Dead (1978). In Night, for instance, Botting understands the zombies as a lumpenproletariat to be thrown 
away in the wake of the postindustrial. Zombies provoke the spectator's anxiety because they represent us as figures of unproductive expenditure. They exemplify economic, social, and technological obsolescence, and for that they can be compared to the dystopian Borg drones: they operate according to a mechanistic desire.

6 '"Death is Irrelevant': Gothic Science Fiction and the Biopolitics of Empire" by Aris Mousoutzanis begins the second section of the book, "Biopower and Capital". The author examines the convergence of monstrous corporeality (gothic influence) and contemporary technoscience as a response to anxieties related to shifts in the relation between contemporary imperial and bio-political discourses. The author finds examples in Chris Carter's The X-Files for its representation of the grotesque and the monstrous, and the figure of the cyborg as found in the Star Trek: Next Generation storyline involving the Borg, whose power illustrates, through their form of colonization relying on bio-politics, contemporary global sovereignty.

7 Sara Wasson's “'A Butcher's Shop where the Meat Still Moved': Gothic Doubles, Organ Harvesting and Human Cloning" puts the figure of doubles in a different light. In fictions by Greg Egan, Michael Marshall Smith, and Kazuo Ishiguro, Wasson studies the double as a critique of the conceptual binary at the center of the contemporary transplant practice. Borrowing Val Scullion's term "Gothic Brechtianism", she underlines how Gothic SF shows the horror of exploitative social processes in black market human tissue, from the perspective of the abject victim.

8 Laurence Davies also points out the capitalist substrate in his "Guillermo del Toro's Cronos, or the Pleasure of Impurity". The movie Cronos was indeed shot at a time of debate around the North America Free Trade Agreement, but it is also interesting for its generic impurity (a mix of fantasy, horror, alternative history), its representation of Mexican culture, and its participation in Gothic as resistance.

9 Still on the link between capital and biopower, Gwyneth Peaty examines the figure of the zombie in 28 Days Later (2002), 28 Weeks Later (2007), and I Am Legend (2007). These movies propose a new representation of the zombie as by-product of biomedicine; in doing so, they express anxiety related to the potential posthuman future of the body, that is to say the loss of ontological wholeness.

10 Emily Adler examines how human identity is disrupted by an excess of biologization through the motive of the skin in "Ruined Skin: Gothic Genetics and Human Identity in Stephen Donaldson's Gap Cycle". The ruination of the skin concentrates the horror generated on the human body by alien genetic engineering. Such engineering is based on the idea of the individual human as reproducible, and thereby conflicts with traditional conceptions of human identity. In spite of its attempts to reconstruct identity around self determination, the novel exudes anxiety about genetic intervention.

11 The last section, "Gender and Genre", pursues reflections on the Gothic genre in its various avatars. Mark P. Williams's chapter, "The Superheated, Superdense Prose of David Conway: Gender and Subjectivity beyond The Starry Wisdom", claims that the intertextual and generic high density in Conway's novella 'Metal Sushi' reflects the apocalyptic theme by creating a textual crisis. As well, this destabilization is tied up with the attack on the representation of gender.

12 Lovecraftian and cyberpunk intertextual influences, along with an aesthetic that blends modernity and postmodernity, also help us to understand the emergence of the New 
Weird - and its potential developments. Jerrilyn McGregor, in "Spatialized Ontologies: Toni Morrisson's Science Fiction in Gothic Space", explores Morrison's blurring of generic conventions, mainly examining the speculative and gothic motives. For instance, if we can take Morrison's imagination to be rooted within the Gothic literary tradition, we will notice a movement from utopia in A Mercy, to dystopia, with Beloved. As well, in her novel Sula, Gothic and science fiction carry the experience of gender.

Nickianne Moody turns her eyes toward the Gothic punk milieu as a narrative diegesis, looking at its creative or pastiche appropriation by popular culture, especially in Blade Runner (1992) and the trading card game Heresy Kingdom Come ${ }^{T M}$. She is impressed by the influence Metropolis (1926) has had in the Gothic punk milieu. In the card game, that milieu provides a space in which to contemplate new social formations in familial institutions, environmental crises, and economic systems. In this way, the game offers youth a way to resist external pressure and to explore forms of knowledge, thereby helping them to face the social environment and their future.

14 Finally, Laura Hilton studies graphic novels in "Gothic Science Fiction in the Steampunk Graphic Novel The League of Extraordinary Gentlemen". This steampunk series borrows from cultural products and literary texts by, for example, Stevenson, Stocker, Verne, and Wells, in order to challenge representations of monstrosity and transgression. Hilton discusses genre-bending in the superheroes Griffin and Hyde. Griffin represents both the Gothic figure of the other and (because he is invisible) the scientific investigation of optical density, while Hyde resembles the Incredible Hulk. Both embody conceptual binaries such as conservatism versus transgression and humanity versus abnormality.

15 Adam Roberts underlines in his Foreword that "Gothic is very far from moribund. It is still in motion, on its way somewhere new". Wasson and Alder's chapter book illustrates this motion convincingly.

\section{AUTHORS}

SOPHIE BEAULÉ

Saint Mary's University 